\title{
Urban and Peri-urban Milk Market Channel Choice Using Multivariate Probit Approach: Evidence from Arsi Highland of Ethiopia
}

Bedilu Demissie Zeleke ( $\sim$ billybedilu@gmail.com )

Arsi University https://orcid.org/0000-0002-0984-5240

Endashaw Terefe Assegidaw

Arsi University

Abiot Deddefo .

Arsi University

\section{Research}

Keywords: Channel choice, Milk production system, Multivariate probit model, Ethiopia

Posted Date: May 28th, 2020

DOI: https://doi.org/10.21203/rs.3.rs-31191/v1

License: (c) (i) This work is licensed under a Creative Commons Attribution 4.0 International License.

Read Full License 


\title{
Urban and Peri-urban Milk Market Channel Choice Using Multivariate Probit Approach: Evidence from Arsi Highland of Ethiopia
}

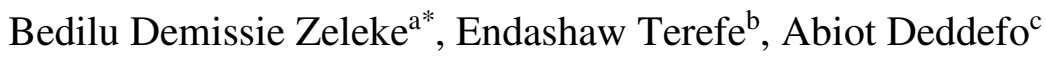 \\ ${ }^{a}$ Department of Agricultural Economics, College of Agriculture and Environmental Science, Arsi University, \\ Ethiopia \\ ${ }^{b \& c}$ Department of Animal Science, College of Agriculture and Environmental Science, Arsi University, Ethiopia \\ Corresponding author’s e-mail: billybedilu@gmail.com/bedilu.zeleke@yahoo.com, Phone number: +251-911-770- \\ 698, Post Address: 193, Ethiopia
}

\begin{abstract}
This article aims at analyzing the factors that affect urban and peri-urban dairy farmers' milk market channel choice in the Arsi Highland of Ethiopia. The reason for focusing on milk is because the product is a key dairy product that contributes to dairy households' economic development, employment creation, and a pathway out of poverty. Four milk marketing channels were thoroughly investigated: a) cooperative channel, b) cafeteria/restaurant channel, c) consumer channel, and d) assembler/trader channel. Primary data collected from 259 dairy farmers through a field survey were used to analyze the simultaneous selection of multiple milk marketing channels. A multivariate probit approach was used and showed that market distance, milk production, artificial insemination (AI), market satisfaction, contractual agreement, quality management, cooperative membership, average milk price, number of the dairy cow, and quantity of milk sold affected farmers milk marketing channel choice. The outcome suggests that policies aimed at strengthening the use of well-organized milk cooperative to access appropriate
\end{abstract}


technology; enhancing milk quality management to ensure milk safety along the milk channel; introducing milk quality incentives; promoting vertical coordination through strengthening the existing informal contractual agreement; establishing advanced milk payment system and improving the volume of milk production could enhance the distribution channel of the study area milk marketing particularly, and developing nation generally.

Keywords: Channel choice, Milk production system, Multivariate probit model, Ethiopia

\section{Introduction}

Ethiopia is believed to manage the largest livestock population in Africa, with the total cattle population estimated to be about 59.5 million (CSA, 2017), a relatively favorable climate for improved dairy breeds and regions with less animal disease-stress that make the country to have a substantial potential for dairy development (Yilma, Guernbableich, \& Sebsibe, 2011). Despite such a substantial potential, the dairy sector in Ethiopia has not been developed to the expected level, for instance, in 2016 Ethiopia's dairy inventory (16 million heads) is considerably larger than the USA inventory ( 9 million heads), yet production in Ethiopia stood at $4 \mathrm{Mt}$, only a fraction of the USA production (96 Mt). Even the cow inventory by itself (at around 11 million heads) exceeds that of the United States. However, in 2014 cow milk production in Ethiopia stood at $3.3 \mathrm{Mt}$. or $0.29 \mathrm{t}$ per cow, far below US yield of around 10t per cow (OECD/FAO, 2017).

Dairy production is a critical issue in Ethiopia livestock-based society, where livestock and its' products are an important pathway out of poverty (EIAR, 2018). It can also provide needed nutritional requirements to meet increasing food security (USAID/Land O'Lakes, 2010). The 
huge livestock resource, favorable agro-ecology for dairying, increasing domestic dairy demand in urban and peri-urban areas, proximity to the international market, and favorable policy are indicators of the importance of dairying in the country (Tegegne, Gebremedhin, Hoekstra, Belay, \& Mekasha, 2013). However, dairy development has been hampered by multi-faceted, production system-specific constraints related to genotype, absence of appropriate farm management practice, long fasting season, and lack of access to (Yilma et al., 2011).

Ethiopian smallholder farmers need to increase the production of dairy products to satisfy household demands for nutrition and income (Mayberry et al., 2017). According to (USAID/Land O'Lakes, 2010) estimates, the demand for dairy products increase from 17 liters per capital to approximately 27 liters per capital in 2020. To fill this gap, the domestic industry will need to expand, dairy cows will have to be more productive and better managed, producers will have to become more market-oriented; otherwise, dairy import bill will continue to rise (Ruben, Dekeba Bekele, \& Megersa Lenjiso, 2017).

Dairy production in Ethiopia is anticipated to increase rapidly in response to the fast-growing demand for livestock products (Tegegne et al., 2013; USAID/Land O'Lakes, 2010). However, in the absence of an adequate remunerating and competitive dairy market, merely focusing on the production aspect may lead to market price collapses and discouraged farmers from buying improved technologies. Therefore, improving the efficiency of dairy product markets is a prerequisite for the dairy transformation (EATA, 2016). That is why most African policy-makers are now shifting their attention from enhancing productivity to improving market competitiveness (Njuki, Kaaria, Chamunorwa, \& Chiuri, 2011). 
Increasing the participation of smallholder farmers' in agricultural markets is dynamically linked to improving food security and reducing poverty in rural areas (Amaya \& Alwang, 2011; Lie, Rich, van der Hoek, \& Dizyee, 2018). The Ethiopian milk marketing system is not well developed, still inefficient and underperforming, which affect the smallholder milk producers, as a result, milk production systems are dominated by the informal marketing system and limited access to the market (Consult, 2008). In 2010, less than $7 \%$ of the annual milk production was marketed at the national level (Yilma et al., 2011). Overcoming these constraints requires a better understanding of the factors that influence smallholder farmers' milk marketing channel choice. Hence, understanding the drivers of smallholder farmers' market channel choice can assist market channel development, smallholder inclusion, and increase farm income (Mmbando, Wale, Baiyegunhi, \& Darroch, 2016).

Dairy farmers in rural setup follow different milk market channels to reach the final consumer (Arinloye et al., 2015; Demissie, Komicha, Kedir, \& Asefa, 2018; Kuma, Baker, Getnet, \& Belay, 2013). The different types of milk market channels that are available for the sampled dairy farm households were cooperative, cafeteria/restaurant, consumer, and assembler/trader channel. However, generally speaking, little is known about the decision making process of dairy farmers regarding milk marketing channel choice and the factors influencing those choices (Tsourgiannis, Eddison, \& Warren, 2008), especially there are few studies on simultaneously modeling selection of different milk market channel in the Arsi highland of Ethiopia. Moreover, it is not known which marketing channels that dairy producers prefer and the factors driving that preference. Even though, understanding the driver can assist in developing the milk market channel, smallholder inclusion, and increase dairy farm income. Cognizant, the study is initiated to investigate how the characteristics of dairy farmers, their production systems, product quality, 
and market context, jointly affect the selection of milk market channel choice in Arsi Highland, Oromia Regional State of Ethiopia.

\section{Data and Research Methodology}

\section{Description of study area}

Arsi zone is found in the central part of the Oromia Regional State. The Zone has four major agro-climatic Zones: Cool (above 3500m), Cool temperate (2500 to 3500m), Warm temperate (1500 -2500m), and lowlands (less than $1500 \mathrm{~m}$ ). Low land constitute about $24.92 \%$ whereas the cool, cool temperate, and the warm temperate constitute $2.74 \%, 22.74 \%$, and $49.60 \%$, respectively (Oromia Finance and Economic Development Bureau, 2011). The CSA (2013) estimate shows that Arsi zone has a total population of 3,202,689 of whom 1,601,757 are men and 1,600,932 are women. Out of the total population, 423,223 are urban inhabitants while the remaining 2,774,465 are rural inhabitants. The major livestock types found in the zone are cattle, sheep, goats, and horses accounting about 2,545,778, 1,587,876, 789,864, and 276,767 respectively in number during the year 2016/17 (CSA, 2017). Mixed agriculture livestock rearing is important next to crop production in the highlands and middle altitude areas of the zone. In such a production system, livestock are the major source of income, nutrition, means of transportation, and source of food for the family. Due to these reasons, farmers are interested to have a large number of livestock populations, irrespective of the availability of enough forage and grazing. The major livestock feeds in the district are forage and crop residue, which are

limited in nutritional values (Gizaw, Tesfay, Mekuriaw, \& Mekasha, 2017; Mekuanint \& Girma, 2017). 
Limuna Bilbilo district is divided into three ecological zones, namely, high land 80\%, Midlatitude 17\%, and Low land 3\%. In the district livestock production is the main economic activity next to crop production. The district has a total population of 219,922 of whom 108,375 are men and 111,547 are women. Out of the total population, 16,634 are urban inhabitants while the remaining 187,222 are rural inhabitants (CSA, 2013). Digeluna Tijo district is divided into two agro-climatic zones; namely Highlands $78 \%$ and mid-altitude $22 \%$. The annual rainfall ranges

from $800-1200 \mathrm{~mm}$ and the annual temperature is from 10 to $20^{\circ} \mathrm{c}$. According to CSA estimate, Digeluna Tijo has a total population of 170,102 of which 83,876 are men and 86,226 are women. Out of the total population, 19,728 are urban inhabitants while the remaining 150,374 are rural inhabitants. Tiyo district is divided into four ecological zones, namely high land cover $31.7 \%$, mid-altitude $42.5 \%$, temperate highland $20.1 \%$, and low land $5.7 \%$. The annual means of temperature range from 15 to 220 and the mean annual rainfall ranges from 900 to $1100 \mathrm{~mm}$. Tiyo district has a total population of estimation of 104,606 of whom 52,202 are men and 52,404 are women. Out of the total population, 9,145 are urban inhabitants while the remaining 95,461 are rural inhabitants (CSA, 2013).

\section{Methods of data collection and Sampling techniques}

The study was conducted in Tiyo, Digaluna Tijo, and Lemuna Bilbilo districts of Arsi Zone, Oromia Regional of Ethiopia during 2016/17 year. Data were collected from both primary and secondary sources. Primary data were collected using a structured questionnaire for crossbreed dairy producers, even though farmers rear both crossbreed and local breeds in the study area. In addition to the questionnaire, an informal survey in the form of focus group discussion was employed to understand the milk marketing structure and the types of marketing channels that 
milk producers use. The interview schedule was conducted with the household head, and sometimes with his spouse. Data were collected on the socioeconomic characteristics of dairy households (HHs), institutional factors, factors affecting milk market channel choices, milk production system, access to dairy inputs, and milk market satisfaction. The secondary data were collected from different sources such as research publications, journals, and annual proceedings, government institutions report such as official reports of Regional Bureau, books, and websites.

Before conducting the actual survey, the enumerators who were working in the district Agriculture and Rural Development Bureau and technical assistants from Arsi University were selected and trained in the techniques of data collection. After training the enumerators, preliminary fieldwork was carried out to gain a tentative insight into the crossbreed milk supply chain. The questionnaire was pre-tested on eight urban and eleven peri-urban cross breed farmers in Arsi zone. As a result, minor alterations were made to the questionnaire prior to the pilot survey. In April 2016, a pilot survey consisting of field interviews was conducted with 36 farmers, 12 in each peasant association (Kebeles). The purpose of the pilot survey was to test and validate the questionnaire design.

A multistage stage sampling design was employed to select the HHs. The base for stratification was urban and peri-urban milk production system ${ }^{1}$. First, three districts were selected based on

\footnotetext{
${ }^{1}$ In this study urban milk production system consists of smallholder's dairy farmers within the town, in our sampling frame, it included eight kebeles: 01, 02, 03, 04, 05, 09, 10 and 11. The peri-urban milk production system consists of dairy farm households in the proximity (within 10 $\mathrm{km}$ radius) of district towns, in our sampling frame, it include eleven kebeles: Dosha, Burka
} 
crossbreed dairy production and marketing potential. Second, urban and peri-urban Kebeles with high milk production and marketing potential were selected with the help of district agricultural experts. Third, probability proportional to the size of the population sampling (PPS) was used to select sampled $\mathrm{HH}$ of 259, based on the list of crossbreed cow from the sampled kebeles. Out of the total sampled HHs, 140 were from urban, whereas 119 were from the peri-urban. Out of the $80 \mathrm{HHs}$ selected from the Tiyo district, 47 were selected from peri-urban, while $33 \mathrm{HHs}$ were selected from urban. Whereas out of the 95 HHs selected from Digaluna Tijo district, 47 respondents were selected from urban, while 48 were selected from peri-urban. From $84 \mathrm{HHs}$ selected from Lemuna Bilbilo district, 46 respondents were selected from urban while 38 respondents were selected from the peri-urban milk production system. We used such a stratification method with a view to composing more homogeneous categories (Dekeba, Beuving, \& Ruben, 2016) in terms of the milk production system, thus resolving the heterogeneity problem of the sample dairy HHs.

\section{Conceptual Framework}

In this article, we focus on modeling dairy farmers' decisions on the selection of different marketing channels, which is anchored on the bases of the Random Utility Model (RUM). RUM is a well-established method for describing discrete agricultural product marketing channel choice behavior (Balsevich, Schuetz, \& Edwin, 2006; Demissie et al., 2018; Kihoro, Irungu, Nyikal, \& Maina, 2016; Mmbando et al., 2016). The model assumes that the decision to participate in a particular dairy marketing channel is based on the theory of rational choice,

Chilalo, Haro Bilalo, Gora Silingo, Ashebeka Wolkite, Gusha Temela, Sagure Mole, Burkitu Alkeso, Chiba Micheal, Bokoji Negeso, and Lemuna Dima. 
which assumes that farmers are rational and will rank alternative market outlet based on his/her expected utility, i.e., profit (Mcfadden, 1986) subject to a set of constraints.

RUM has been developed to describe channel choice among mutually exclusive discrete alternatives (Baltas \& Doyle, 2001) and received considerable academic attention. A dairy farmer's decision to participate in a given market channel or not, as well as their simultaneous use, is made by evaluating the gains in expected utility, taking into account the related investment, profit, and transaction costs associated with milk marketing. If this expected utility is positive and higher than alternative marketing channels, dairy farmers will select this market channel that shows the most positive utility. The choice of the marketing channel was based on the dairy farms' socioeconomic characteristics and relevant factors influencing the choice entrenched in each channel.

The dairy producers were mapped into four dairy market channels $N(4)$ : milk sale to the cooperative channel, cafeteria/restaurant channel, consumer channel, and assembler/trader channel. The utility of dairy farmer participating in the market channel $j$, is represented by $U_{i j}$. The dairy farmer does an expected benefit-marginal cost calculation based on the utilities achieved by selling milk to one marketing channel or another. The utility, $U_{i j}$, for each dairy farmer choosing a particular alternative, is specified as a linear function of the vector of channelspecific parameters, $\left(\beta_{j}\right)$, and the attributes of that alternative $\left(X_{i j}\right)$ and a stochastic error component $\left(\varepsilon_{i j}\right)$, assumed to be independently $N\left(0, \sigma^{2}\right)$ distributed (Equation 1$)$ :

$U_{i(j=k)}=\beta_{j=k} X_{i j}+\varepsilon_{i j} \quad \forall j \in N$ 
Dairy farmer $i$ 's choice a marketing channel is a function of farmer's attributes, institutional factors, and channel attributes (Greene, 2000). Utilities are latent, but the market channel choice made by the dairy farmer reveals which one provides the greatest utility. From the dairy farmer's decision maker's perspective, the best alternative channel is simply the one that maximizes net private benefit at the margin. The probability of choosing an alternative channel is equal to the probability that the utility of that particular alternative channel is greater than or equal to the utilities of all other alternatives in the channel choice set. The dairy farm household selects market channel $j=k$ if

$U_{i(j=k)}>U_{i(j \neq k)} \quad \forall k \neq j$

where $U_{i j}$ denotes a random utility associated with the dairy channel $j=k$; and $\beta_{j=k} X_{i j}$ is an index function denoting the producer's average utility associated with the alternative. The second term $\varepsilon_{i j}$, denotes a random error that is specific to a producer's utility preference.

\section{Multinomial Probit Model}

To analyze the dairy market channel choice descriptive and econometric approaches were complementarily used. Since the results from the descriptive statistics did not allow for isolating the marginal effects of specific explanatory variables for the desecrate milk marketing channel choice, we ran multivariate probit regressions using the mvprobit command and for the companion program for post-estimation prediction, mvppred in STATA 14 software.

The sampled dairy farmers reported that they access multiple milk channels to sell their milk. We assume that dairy farmers are using these multiple sources of milk marketing channels 
simultaneously. The proposed methodology will derive insight into the dairy farmers' socioeconomic and institutional factors that lead to their utilization of different marketing channels. The null hypothesis of this research is that there is no significant difference between the socioeconomic and institutional characteristics of dairy farmers and their access to milk market channels. This implies that dairy farmers irrespective of their socioeconomic and institutional characteristics will use a given milk market channel.

The empirical specification of the dairy channel choice decision over the four milk marketing channel can be modeled in two ways, by either multinomial or multivariate regression analysis. Because estimating the probability of dairy channel choice using Ordinary Least Squares (OLS) yields inconsistent parameter estimates because of the discrete nature of market channel choice (Gujarati \& Sangeetha, 2007). On the other hand, binary choice models, i.e., probit/logit restrict the choice probability within two-equation model (Greene, 2000). The advantage of the multivariate probit over the bivariate probit is that a series of bivariate probit equation models can be estimated jointly using the method of simulated maximum likelihood, as opposed to only two equations probit model (Tapsuwan, Burton, \& Perriam, 2010). Besides, the main novelty of the multivariate probit approach is to study the joint-decision making process of dairy farmers' milk market channel choice strategies and to identify the milk market channel's potential substitutability or complementarily.

The multivariate probit also allows the error terms to be correlated, with joint normally distributed error for all $i$ with $N \sim(0,1)$ and can be used to estimate the parameters of more than two successive dichotomous choice questions (Araña \& León, 2007). Several market channel choice studies have been done by using a multinomial logit (Abera Negeri, 2017; 
Demissie et al., 2018; Emana, Ketema, Mutimba, \& Yousuf, 2015; Kihoro et al., 2016; Kuma et al., 2013; Mmbando et al., 2016; Nyaga, Nyikal, \& Busienei, 2016), however, few studies have been done using a multivariate probit model (Abera, 2016; Arinloye et al., 2015; Hailu, 2017; Tarekegn, Haji, \& Tegegne, 2017). One of the underlying assumptions of multinomial logit models is the independence of irrelevant alternative that is error terms of the market channel choice equations are mutually exclusive (Greene, 2000). However, the market channel choices among the milk market channel are not mutually exclusive as farmers are accessing more than one marketing channel at the same time (Abera, 2016) for this study. Therefore, the random error components of the dairy market channel choice may be correlated. Subsequently, we consider using a multivariate probit model which allows for the possible contemporaneous correlation in the milk market channel choice to access the four market channels simultaneously.

The observed outcome of dairy market channel choice can be modeled following RUM. It is assumed that given dairy producer farmer $i$ in making a decision considering not exclusive alternatives that constituted the market channel choice set $K^{\text {th }}$ of milk market channel outlets, the choice sets may differ according to the decision-maker. Consider the $i^{\text {th }}$ dairy farm household $(i=1,2, \ldots N)$ facing a decision problem on whether or not to choose the available market channel outlets. Let $U_{k}$ represent the benefit of the dairy farmer to choose the $K^{\text {th }}$ milk market outlet: Where $K$ denotes the choice of cooperative $\left(Y_{1}\right)$, cafeteria/restaurant $\left(Y_{2}\right)$, the consumer $\left(Y_{3}\right)$, and assembler/traders $\left(Y_{4}\right)$. The dairy farmer decides to choose the $K^{\text {th }}$ milk market channels if $Y_{i k}=U_{k}-U_{o}>0$. The net benefit $\left(Y_{i k}\right)$ that the farmer derives from choosing a milk market channel is a latent variable determined by observed explanatory variable $\left(X_{i}\right)$, 
$X_{i}$ represents the set of explanatory variables related to dairy farmers and farm characteristics, and institutional factors, and the error term $\left(\varepsilon_{i}\right)$ :

$$
Y_{i k}^{*}=X_{i}^{\prime} \beta_{k}+\varepsilon_{i} \quad\left(K=Y_{1}, Y_{2}, Y_{3}, Y_{4}\right)
$$

Thus, the econometric approach for this study is by using the indicator function; the unobserved preferences in Eq. (3) translate into the observed binary outcome equation for each choice as follows:

$$
Y_{i k}=\left\{\begin{array}{l}
1 \text { if } Y_{i k}^{*}>0 \\
0 \text { Otherwise }
\end{array} \quad\left(k=Y_{1}, Y_{2}, Y_{3}, Y_{4}\right)\right.
$$

In the multivariate model, where the choice of several market channel outlets is possible, the error terms may be correlated. Therefore, instead of independently estimating equations, they are considered to be a multivariate limited-dependent-variable model, in which the four error terms follow a multivariate normal distribution (MVN) with zero conditional mean and variance normalized to unity (for identification of the parameters) where $\left(\mu_{x 1}, \mu_{x 2}, \mu_{x 3}, \mu_{x 4}\right) M V N \sim$ $(0, \Omega)$ and the symmetric covariance matrix $\Omega$ is given by:

$$
\operatorname{Cov}[\Omega]=\left[\begin{array}{cccc}
1 & \rho_{x 1 \times 2} & \rho_{x 1 \times 3} & \rho_{x 1 \times 4} \\
\rho_{x 2 x 1} & 1 & \rho_{x 2 x 3} & \rho_{x 2 x 4} \\
\rho_{x 3 x 1} & \rho_{x 3 \times 2} & 1 & \rho_{x 3 x 4} \\
\rho_{x 4 x 1} & \rho_{x 4 \times 2} & \rho_{x 4 \times 3} & 1
\end{array}\right]
$$

Of particular interest are the off-diagonal elements in the covariance matrix, which represent the unobserved correlation between the stochastic components of the different types of outlets. This assumption means, that Eq.(6) generates a multivariate probit model that jointly represents the 
decision to channel choice particular milk market outlet. This specification with non-zero offdiagonal elements allows for correlation across terms of several latent equations, which represents unobserved characteristics that affect the choice of alternative channel outlets.

Following the formula used by Cappellari \& Jenkins (2003), the log-likelihood function associated with a sample outcome is then given by:

$\ln L=\sum_{i=1}^{N} \omega_{i} \ln \Phi\left(\mu_{i}, \Omega\right)$

where $\omega$ is an optional weight for observation $i=1, \ldots, N$ and $\Phi_{i}$ is the multivariate standard normal distribution with arguments $\mu_{i}$ and $\Omega$, where $\mu_{i}$ can be denoted as:

$\mu_{i}=\left(K_{i 1} \beta_{1} X_{i 1}, K_{i 2} \beta_{2}, K_{i 3} \beta_{3} X_{i 3}\right)$, while $\Omega_{i k}=1$ for $j=k$ and

$\Omega_{i k}=\Omega_{k i}=K_{i j} K_{i k} \rho_{j k}$ for $J \neq k, k=1,2,3, \ldots$ with $K_{i k}=2 Y_{i k}-1$

Clearly, the log-likelihood function depends on the standard normal distribution function $\Phi_{i}($.$) .$

Previous studies highlight that farmers' milk market channel choice was affected by sales price, milk output, personal relationship, access to information, transaction cost and easements of payment (Mutura, Nyairo, Mwangi, \& Wambugu, 2016; Tsourgiannis et al., 2008). Other factors affecting milk market channel choice include the distance to a collection center, education level, membership to farmers' groups, extension contact, number of dairy cows owned, and better milk price (Demissie et al., 2018; Kuma et al., 2013; Moturi, Obare, \& Kahi, 2015). A recent study in Kenya showed that farmers preferred green gram market channels where they incur low production and transaction cost, and that offer a higher price (Kihoro et al., 2016) comparatively. 
Although a study in Benin revealed that Pineapple farmers selected market channels with high values, know-how for coping, and complying with quality issues (Arinloye et al., 2015).

A study on maize and pigeon pea producers in Tanzania showed five major factors affecting market selection, such as transaction costs, access to credit, household wealth, extension services, and social capital (Mmbando et al., 2016). Another study on honey producer market outlet choice in Ethiopia revealed seven factors affecting market channel choices, such as quantity sold, beekeeping experience, extension contact, distance to the nearest market, market information, cooperative membership, and trust in buyers (Tarekegn et al., 2017). Although a study in Rural South Africa on cattle marketing channels showed that transaction costs, festive season, knowledge of the buyer, volume supplied and farmer's age affected cattle marketing channel choice (Ndoro, Mudhara, Chimonyo, \& Hitayezu, 2015). Following the above literature, the present study further investigates factors affecting milk market channel choice in the urban and peri-urban area of the Arsi highland of Ethiopia, extending this list to drivers' factors such as market satisfaction, contractual agreement, quality management and Artificial Insemination (AI).

\section{Hypothesized variables}

The potential variables, which were supposed to influence dairy producers' milk market channel choice, need to be explained. Hence, the explanatory variables expected to have influencedependent variable are summarized as follows (Table 1):

Table 1 Hypothesized variable that determines dairy producers' market channel choice

Variable
Type

Expected sign 


\section{Dependent variables}

Milk market channel $Y_{1}=$ Producer choice cooperative channel
choice
\[ \begin{array}{l}Y_{2}=\text { Producer choice Cafeteria/Restaurant } \\ \text { channel } \\ Y_{3}=\text { Producer choice Consumer channel } \\ Y_{4}=\text { Producer choice Traders channel }\end{array} \]

\section{Independent variable}

Gender of $\mathrm{HH}$

Dummy, $1=$ Male $0=$ Female

Education of $\mathrm{HH}$

Discrete, $1=$ Formal Education 0=Otherwise

$+$

Family size

Continuous, Family size in number

Market Distance

Continuous, Distance to the nearest market in

$\mathrm{Km}$

Land size

Continuous, Total land holding in hectare

$+$

Milk production

Continuous, Milk produced per day per $\mathrm{HH}$ in

$+$

liter

Artificial Insemination Dummy, $1=$ Access to AI services $0=$ Otherwise

(AI) 
Training

Extension

Market satisfaction

Contractual Agreement

Price Information

Quality Management

Cooperative Member

Average Milk Price

Number of Dairy Cow

Quantity Sold
Dummy, 1=Received dairy management training $0=$ Otherwise

Dummy, $1=$ Received extension $0=$ Otherwise

Dummy, 1= Satisfied with milk marketing $0=$ Otherwise

Dummy, 1= Have contractual agreement $0=$ Otherwise

Dummy, $1=$ Know market information before sale $0=$ Otherwise

Continuous, $1=$ Milk Standardization $0=$ Otherwise

Dummy, $1=$ Cooperative member $0=$ Otherwise Continuous, Average milk price/liter in $+$ Ethiopian Birr

Continuous, Number of dairy cows/household

$+$ Continuous, Quantity of milk sold per day per $+$

\section{Results and Discussion}




\section{Socioeconomic characteristics of the sampled milk producers}

The socioeconomic and institutional characteristics of the dairy farm HHs presented in table 2 indicate that the majority of the dairy HHs preferred cafeteria/restaurant (35.91\%) and consumer (35.91\%) channels. Nearly $15.44 \%$ sold their milk to the assembler/trader channel at the nearby place and only $12.74 \%$ sold to cooperative outlets. The overall mean family size for the sampled respondents was 6 in number; the mean household size by milk market channel was 7.09, 5.86, 5.72, and 5.72 with cooperative, cafeteria, consumer, and assembler/trader channels. Dairy farmers who sold to cooperative had relatively more family size on average (7.09) than the other milk market channels.

Table 2 Mean HH characteristics by milk market outlets

\section{Mean (standard deviation) of market channels}

\begin{tabular}{lcccc}
\cline { 2 - 4 } \multicolumn{1}{c}{ Variable } & Cooperative & Cafeteria & Consumer & Assembler \\
& & & & \\
\hline Family size (number) & $7.09(4.42)$ & $5.86(2.34)$ & $5.72(2.18)$ & $5.72(2.18)$ \\
Market distance (Km) & $3.82(2.57)$ & $1.49(1.63)$ & $1.73(1.9)$ & $1.73(1.9)$ \\
Landholding (ha) & $2.93(3.15)$ & $1.33(2.26)$ & $1.08(2.2)$ & $1.08(2.19)$ \\
Milk yield (liter/head/day) & $7.68(3.97)$ & $9.95(4.33)$ & $9.18(4.15)$ & $9.18(1.38)$ \\
Milk yield (liter/HH/ day) & $17.91(15.71)$ & $17.74(9.48)$ & $15.92(7.62)$ & $15.85(10.5)$ \\
& & & & $10.78(1.97)$
\end{tabular}




$\begin{array}{lllll}\text { Dairy cows (HH/herd /number) } & 3.76(2.55) & 2.69(1.43) & 2.53(0.98) & 2.53(0.98) \\ \text { Milk sold (liter/ HH/day) } & 14.24(13.89) & 15.46(8.36) & 14.05(7.35) & 14.05(7.35)\end{array}$

Source: Own estimations, 2017

The average distance traveled to the nearest milk market by the sampled $\mathrm{HH}$ to sell their milk was $2.19 \mathrm{~km}$. It was relatively highest for sampled milk producers who targeted cooperative channel $(3.82 \mathrm{~km})$, and lowest to HHs that had access to consumer and assembler/trader $(1.73$ $\mathrm{km}$ ) channels. The landholding is one of the important resources for dairy farming, the mean landholding size was highest for dairy HHs that had access to cooperative (2.93 ha) channel and the lowest for HHs who had access to consumer and assembler (1.08 ha) channel.

In the study area, hand milking is the sole milking method and cows were hand milked twice daily, on average daily milk yield per cow for the sample dairy $\mathrm{HH}$ was 9 liter and dairy farm HHs with the average highest yield $(9.95 \pm 4.33)$ target cafeteria channel. The result was comparable to values of 10 liters/day/cow reported by Yami et al. (2012) for improved breeds in Lemuna Bilbilo district and 6.45 liters/day/cow for Holeta Agricultural Research Center (EIAR, 2018). The average daily milk production of dairy cows was higher in urban (10.12 \pm 0.37 liters/head/day) than the peri-urban $(8.24 \pm 0.38)$ systems. The result is in agreement with (Tegegne et al., 2013). The average milk production volume of the study $\mathrm{HHs}$ was 14.45 liter/day/HH. On average 14.24, 15.46, 14.05, and 14.05 liter of milk per day per dairy HHs was accessed by the cooperative, cafeteria, consumer, and assembler milk market channels, respectively. The maximum milk yield/day/crossbreed was found to be 20 liters, suggesting the 
potential to improve milk yield/crossbreed cow from the current average of 10 liters/day/crossbreeds to 20 liters/day/cow, this result is in line with (Yami et al., 2012).

The average price of milk was 10.38 Ethiopian Birr (ETB) per liter. The average price varied across milk market channels. On average, cooperative (9.63 ETB/liter) offered the lowest price among the available channel, the highest price was offered by consumer and assembler channel (10.78 ETB/liter). Unlike the large scale commercial milk enterprises that character many developed countries, milk production in Ethiopia is dominated by smallholder producers, the mean dairy cow ownership of sampled HHs who had access to the cooperative, cafeteria, consumer, and assembler/trader channels was 3.76, 2.69, 2.53 and 2.53 crossbreeds/herd, respectively. This indicates that dairy farming HHs that owned large cross breeds accessed the cooperative channel, because of the cooperatives capacity to purchase large amounts of milk. Dairy cooperative societies take the larger segment of the marketed milk volume in the study area $(14.24 \pm 13.89)$, while the largest milk volume was marketed through the cafeteria (15.46 \pm 8.36$)$ channel. For the remaining channels, the mean marketed volume was 14.05 liter, and most of the producers and marketing channel actors sold their milk without processing or adding value.

The urban and peri-urban dairy farming systems are an important emerging component of the milk production system. Out of the total sampled respondents (see Table 3), 54.05\% followed the urban dairy farming system, while the remaining (45.95\%) followed the peri-urban milk production system. Most of the urban milk producers (24.32\%) targeted the consumer channel, whereas the peri-urban milk producers (14.29\%) supplied their milk products to the cafeterias channel. The result shows that $57.91 \%$ of the sampled HHs were male-headed; most of the male 
respondents' targeted consumers $(20.46 \%)$ channel, females' targeted the cafeteria (17.37\%) channel.

Out of the total sampled dairy respondents, $89.58 \%$ perceived dairy production as a business, of which 32.82 and $32.43 \%$ targeted consumer and cafeteria channels, respectively. It can be inferred that most of the sampled dairy HHs who supplied their milk to the consumer and cafeteria channel were market-oriented, relative to the cooperative and assembler channel. This result is inconsistent with Yami et al. (2012) who reported that dairy farmers of the Lemuna Bilbilo district do not perceive dairy production as a business.

Artificial Insemination (IA) is an important technology to improve the genetic potential of crossbred cows, out of the total sample respondents $75.98 \%$ had easy access to the AI. Of which, dairy farmer HHs who target cafeteria and consumer channel accounts for 32.43 and $32.82 \%$, respectively, the plausible reason for this is that most of the AI technician and the district health clinics were based in district urban cities. This result is in line with Yami et al. (2012). On average, about 27.03 and $62.16 \%$ of the sampled dairy farmers had access to training and extension services, respectively. 
Table 3 Proportion of dairy farm HH characteristics by milk channel

\section{Proportion (\%) of the market channel}

\begin{tabular}{|c|c|c|c|c|c|}
\hline \multirow{3}{*}{ Variable } & \multirow{3}{*}{ Category } & \multirow{3}{*}{$\begin{array}{c}\text { Cooperative } \\
(\mathrm{N}=33)\end{array}$} & \multirow{3}{*}{$\begin{array}{l}\text { Cafeteria } \\
(\mathrm{N}=93)\end{array}$} & \multirow{3}{*}{$\begin{array}{l}\text { Consumer } \\
\qquad(\mathrm{N}=93)\end{array}$} & \multirow{3}{*}{$\begin{array}{l}\text { Assembler } \\
(\mathrm{N}=40)\end{array}$} \\
\hline & & & & & \\
\hline & & & & & \\
\hline \multirow[t]{2}{*}{ Farming system } & Urban & 1.93 & 21.62 & 24.32 & 6.18 \\
\hline & Peri-urban & 10.81 & 14.29 & 11.58 & 9.27 \\
\hline \multirow[t]{2}{*}{ Gender } & Female & 3.09 & 17.37 & 15.44 & 6.18 \\
\hline & Male & 9.65 & 18.53 & 20.46 & 9.27 \\
\hline \multirow[t]{2}{*}{ Production Purpose } & Home consumption & 1.54 & 3.47 & 3.09 & 2.32 \\
\hline & For sale & 11.20 & 32.43 & 32.82 & 13.13 \\
\hline \multirow[t]{2}{*}{ Access to AI } & Difficulty accessing & 3.86 & 4.63 & 8.88 & 6.56 \\
\hline & Easy access & 8.88 & 31.27 & 27.03 & 8.88 \\
\hline \multirow[t]{2}{*}{ Received training } & No & 7.34 & 28.19 & 28.19 & 9.27 \\
\hline & Yes & 5.41 & 7.72 & 7.72 & 6.18 \\
\hline \multirow[t]{2}{*}{ Extension contact } & No & 3.86 & 16.22 & 13.13 & 4.63 \\
\hline & Yes & 8.88 & 19.69 & 22.78 & 10.81 \\
\hline Market satisfaction & No & 6.95 & 23.17 & 16.22 & 8.11 \\
\hline
\end{tabular}




$\begin{array}{lccccc} & \text { Yes } & 5.79 & 12.74 & 19.69 & 7.34 \\ \begin{array}{lcccc}\text { Contractual } \\ \text { agreement }\end{array} & \text { No } & 9.65 & 30.50 & 32.43 & 13.90 \\ & \text { Yes } & 3.09 & 5.41 & 3.09 & 1.54 \\ \text { Price information } & \text { No } & 4.25 & 7.72 & 10.04 & 1.54 \\ & \text { Yes } & 8.49 & 28.19 & 25.87 & 13.90 \\ & \text { No } & 7.34 & 27.41 & 33.98 & 10.81 \\ \text { Quality } & \text { Yes } & & & & \\ \text { management } & \text { No } & 5.41 & 8.49 & 1.93 & 4.63 \\ \text { Cooperative } & \text { Yes } & 5.02 & 31.27 & 32.82 & 11.20 \\ \text { membership } & & 7.72 & 4.63 & 3.09 & 4.25\end{array}$

Source: Own estimation, 2017

Farmers were asked to describe their market satisfaction level in each of the milk market channels in which they sell their milk. They were considered to have low market satisfaction when the milk buyer is the dominant actor in price setting, and they were considered to have high market satisfaction when they have higher bargaining power in the milk transaction. Table 3 shows that out of the total respondents, about $45.56 \%$ were satisfied with marketing their milk, of which the majority targeted selling their produce to consumer channel (19.69\%). Revealing that, farmers who sold their milk to the consumer channel have relatively better bargaining power when milk price is agreed. On the contrary, HHs who targeted cooperative channel (5.79\%) has the lowest bargaining power on price relative to the other milk market channel. 
Table 3 shows that $86.87 \%$ of sampled dairy farmers do not have written contractual agreements with their buyers, therefore there is a need to start a binding contractual arrangement between milk purchasers and with their supplying farmers. About $28.19 \%$ of dairy farmers who supplied to the cafeteria channel used information on milk market prices before they decided to sell their milk, as compared with those using consumer (25.87\%), assembler (13.09\%) and cooperative (8.495) channels.

Milk quality management is an important food safety standard requirement in modern milk market channels to ensure food safety. However, out of the total sampled HHs, only $20.46 \%$ of respondents practiced unregulated milk quality management. Moreover, there is no milk quality test at each stage during the transportation of milk to ensure adherence to food safety standards. Therefore, there is a need to establish a milk cool center along the chains with chillers to insure milk quality along the chain, as cooling is the most widely used technique for preserving raw milk. Most of the dairy HHs (79.76\%) did not have membership in dairy farmers' cooperative societies. Most of the dairy farmers who supplied to cooperative (7.72\%) participated in a dairy milk production and marketing cooperative, as compared to dairy farmers who supplied to cafeteria 4.63\%), assembler (4.25), and consumer (3.09\%) channel.

\section{Determinants of milk producer's market channel choices}

A multivariate probit model was used to test the effects of the different socioeconomics and institutional factors on the selection of a particular milk market channel. Table 4 provides the estimation results of the multivariate probit model. The main novelty of this approach is to study the joint-decision making process of milk market channel choice between different strategies and to identify potential substitutability or complementarity of milk market channels. 
Looking at Table 4, the Wald chi-square statistic $\left.\left(X^{2}(68)=126.8, p=0.0000\right)\right)$ that was used to test for the overall significance of the variables included in the model is significant $(\mathrm{p}<0.01)$. This result indicates that the subsets of coefficients of the model are jointly significant and the explanatory power of the factors included in the model is satisfactory, thus the multivariate probit model fits the data reasonably well. Likewise, the model is significant because the null that the channel choice decision of the four milk market channel choice is independent was rejected ( $\mathrm{p}<0.01)$. The correct prediction rate of $10,36,39$, and $19 \%$ shows that the models have a satisfactory prediction.

The result of the likelihood ratio test in the model $\left(L R X^{2}(6)=124.195, X^{2}>p=0.0000\right)$ of the null hypothesis of independency between the milk market channels decision ( $\rho_{21}=\rho_{31}=\rho_{41}=\rho_{32}=\rho_{42}=\rho_{43}=0$ ) is significant at $1 \%$. Therefore, the null hypothesis that all the $\rho$ values are jointly equal to zero is rejected, indicating the goodness-of-fit of the model. Hence, this verifies that there are differences in milk market channel choice behavior among dairy farmers, which are reflected in the likelihood ratio statistics. Indicating that, the separate estimation of channel choice decision of these channels is biased, and the decisions to choose the four milk market channel choice are interdependent decision.

The multivariate probit model also allows us to identify the potential correlation between different milk market channel choices. The results indicate that substitutability exists between most of the milk market channels such as consumer and cooperative channel; consumer and cafeteria/restaurant channel; assembler and cafeteria/restaurant channel; assembler and consumer channel. While complementarity exists between a few of the milk market channels such as cafeteria/restaurant and cooperative channel; and assembler/trader and cooperative channels. 
Table 4 Multivariate probit model: Factors associated with milk market channel choice

\section{Dairy Milk Marketing Channels}

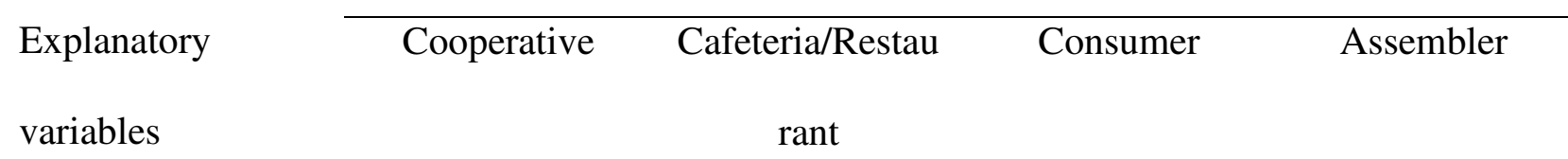

Coef. Std. Coef. $\quad$ Std. $\quad$ Coef. $\quad$ Std. Coef. Std. Err. Err. Err. Err.

\begin{tabular}{|c|c|c|c|c|c|c|c|c|}
\hline Gender & -.146 & .337 & -.274 & .185 & .259 & .182 & .088 & .207 \\
\hline Education & -.009 & .415 & .021 & .221 & -.071 & .215 & .097 & .247 \\
\hline Family Size & .053 & .056 & -.008 & .037 & -.03 & .041 & -.017 & .045 \\
\hline Market Distance & $.027 * *$ & .093 & $-.125 * *$ & .057 & -.031 & .055 & $.215 * *$ & .063 \\
\hline Land Size & .009 & .07 & .051 & .047 & -.086 & .046 & -.091 & .061 \\
\hline Milk & $.115 * *$ & .052 & .006 & .034 & $-.086 *$ & .048 & -.009 & .038 \\
\hline \multicolumn{9}{|l|}{ Production/HH/da } \\
\hline \multicolumn{9}{|l|}{$\mathrm{y}$} \\
\hline Access to AI & .055 & .376 & $.542 * *$ & .226 & -.227 & .225 & - & .222 \\
\hline & & & & & & & $.548 * *$ & \\
\hline Training & .239 & .39 & .083 & .205 & -.066 & .200 & .008 & .232 \\
\hline
\end{tabular}




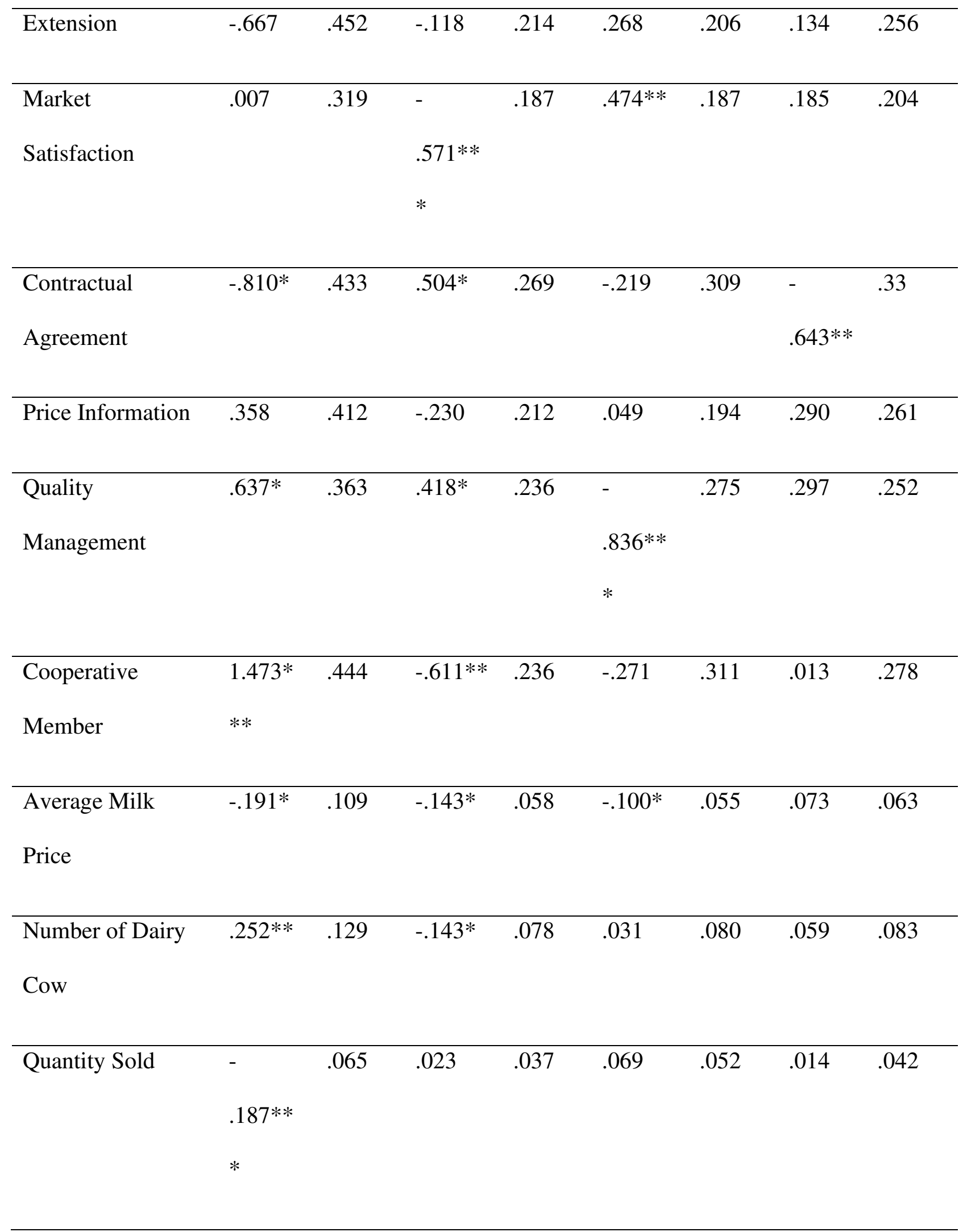




\begin{tabular}{lllllllll}
\hline Constant & -.557 & 1.301 & .954 & .770 & -.86 & .748 & -2.282 & .909
\end{tabular}

Correlation between dairy channels

$\begin{array}{llllll}\text { Cafeteria \& } & .866 & .127 & \text { Consumer \& Cafeteria. } & -.888^{* * *} & .066\end{array}$

Coop. $(\rho 21)$

\begin{tabular}{lllllll}
\hline Consumer \& & $-.227^{*}$ & .123 & & Trader \& Cafeteria $(\rho 42)$ & -.156 & .139
\end{tabular}

Coop. $(\rho 31)$

$\begin{array}{llllll}\text { Trader \& Coop. }(\rho 41) & .222 & .173 & \text { Trader \& Consumer } & -.087 & .126\end{array}$ $(\rho 43)$

Likelihood ratio test of $\rho 21=\rho 31=\rho 41=\rho 32=\rho 42=\rho 43=0: \quad X^{2}(6)=137$, Prob $>X^{2}=0.000$, Log likelihood $=-3772.598$, Wald $X^{2}(68)=126.8, \operatorname{Pr} o b>X^{2}=0.000$, Number of observation $=259$.

Note: $*, * *$, and $* * *=$ significance level at 10,5 , and $1 \%$, respectively.

Source: Own estimations, 2016

Separately considered, the $\rho$ values $\left(\rho_{i j}\right)$ indicate the degree of correlation between each pair of dependent variables. $\rho_{31}$ (the correlation between the choice for consumer and cooperative channel) and $\rho_{32}$ (the correlation between the choice for consumer and cafeteria/restaurant channel) are negatively interdependent and significant at the 10 and $1 \%$ probability leave, respectively (Table 4). This finding leads us to the conclusion that dairy farmers delivering milk to the consumer channel are less likely to deliver to the cooperative channel $\left(\rho_{31}\right)$. Equally, those 
involved in consumer marketing channels are less likely to send their milk to the cafeteria/restaurant channel $\left(\rho_{32}\right)$.

Based on the result of the multivariate probit model in Table 4 , most of the variables were significant at more than one milk market channel choice while one variable was significant in only one market outlet. Out of the seventeen explanatory variables included in the model, eight variables (such as marker distance, milk production, contractual agreement, quality management, cooperative membership, average milk price, number of dairy cow and quantity sold) significantly affected cooperative channel; eight variables (such as market distance, artificial insemination, market satisfaction, contractual agreement, quality management, cooperative membership, average milk price, and number of dairy cows) significantly affected cafeteria/restaurant channel; four variables (such as milk production, market satisfaction, quality management, and average milk price) affected consumer channel; and three variables (such as market distance, artificial insemination, and contractual agreement) significantly affected assembler/trader milk market channel at different probability and significance levels.

Distance from the nearest milk market is positively associated with the likelihood of selling milk to the cooperative $(\mathrm{p}<0.05)$ and assembler/trader channel $(\mathrm{p}<0.01)$, however. Distance from the nearest milk market negatively and significantly $(\mathrm{p}<0.01)$ influenced the likelihood of choosing the cafeteria/restaurant channel. The positive relation of distance to the nearest milk market and the likelihood of choosing a cooperative were due to the fact that the cooperative could afford the cost of collecting milk from such a distance place. Likewise, assembler purchase milk at the farm gate from dairy $\mathrm{HHs}$ by doing door to door collection which reduces the transaction cost associated with milk marketing. This result is consistent with the study by 
Bardhan et al. (2012), Moturi et al. (2015), and Tarekegn et al. (2017). Regarding, the cafeteria/restaurant channel, the plausible explanation for the negative association with distance is that most of the cafeterias/restaurant requires dairy farm HHs to deliver their milk to the cafeteria/restaurant on a daily base, which is time taking and transaction cost inducing requirement for the dairy farm households.

Quantity of milk production per HH per day influenced the likelihood of choosing a cooperative market channel positively $(\mathrm{p}<0.05)$ and influenced negatively $(\mathrm{p}<0.01)$ the likelihood of choosing consumer channel, ceteris paribus. This result indicates that dairy farmers producing a large volume of milk were more likely to sell to the cooperative channel, whilst farmers with small production volumes were more likely to prefer the consumer channel. This result is consistent with Kumar et al. (2011), Moturi et al. (2015), and Tsourgiannis et al. (2008) who revealed a positive relationship between the volume of milk produced and the choice of cooperative channel.

Milk market satisfaction is negatively and significantly $(\mathrm{p}<0.001)$ associated with the likelihood of targeting cafeteria/restaurant channel and positively $(\mathrm{p}<0.05)$ associated with the likelihood of selling milk to the consumer channel, ceteris paribus. According to Arinloye et al. (2015) farmer were considered to have high bargaining power when they have full control of the price in the transaction. It can be inferred that dairy farmers who sell their milk to the consumer channel have higher bargaining power in price setting and lower bargaining when the buyer is the cafeteria/restaurant channel. The result corroborates the findings Kuma et al. (2013).

Contractual agreement is negatively and significantly $(\mathrm{p}<0.01)$ associated with the likelihood of choosing cooperative and assembler channels $(\mathrm{p}<0.01)$, ceteris paribus. These findings were 
consistent with Arinloye et al. (2015), who revealed that farmers default on agreements by selling their produce to other buyers who offer higher prices and negatively correlated with the decision to choose the rural market. This is plausibly explained by the positive and significant ( $\mathrm{p}$ $<0.1)$ correlation between unenforceable monthly contractual agreement and the likelihood of targeting the cafeteria/restaurant channel.

Access to $\boldsymbol{A I}$ is positively associated with the likelihood of choosing the cafeteria/restaurant channel $(\mathrm{p}<0.05)$ and negatively $(\mathrm{p}<0.05)$ associated with the likelihood of targeting to the assembler channel, ceteris paribus. The plausible reason for this could be, dairy HHs who supplied their milk to the cafeteria/restaurant channel were more likely to use special inputs like artificial insemination to benefit from the improved breed with high milk production and productivity.

Milk quality management has a positive and significant $(\mathrm{p}<0.05)$ influence on the likelihood of targeting cooperative and cafeteria/restaurant channel choice and influenced negatively ( $\mathrm{p}<$ 0.001) the likelihood of choosing the consumer channel, ceteris paribus. Revealing that, cooperative and cafeteria/restaurant channel are the market channel with the highest quality requirements and dairy $\mathrm{HHs}$ who choose to supply to cooperative and cafeteria/restaurant channel are those who can comply with informal quality norms and formal standards. We also found that dairy farmer HHs with lower milk quality often chooses to supply their milk to the consumer channel. The result corroborates the findings by Ishaq et al. (2017) and Kumar et al. (2011), who revealed that performing quality inspection had a positive relationship with the modern milk channel. 
Cooperative membership has a positive and significant $(\mathrm{p}<0.001)$ influence on the likelihood of choosing the cooperative channel, ceteris paribus. Thus, as members of milk production and marketing cooperatives, HHs have the responsibility to supply to its cooperative from their production as a norm of cooperative, even if they sell to other outlets for immediate cash need. The variable is also negatively associated $(\mathrm{p}<0.05)$ with the likelihood of selling milk to the cafeteria channel choice. The negative relation indicates that dairy HHs who were a member of cooperative are less likely to choose cafeteria channel compared to those who are not members, due to the incentives cooperative has over cafeteria/restaurant such as greater economies of scale, as well as reducing transaction cost. The result corroborates the findings by Moturi et al. (2015).

Contrary to the expectation, the average milk price is negatively and significantly $(\mathrm{p}<0.01)$ associated with the likelihood of choosing cooperative, cafeteria/restaurant and consumer channel, ceteris paribus. These reveal that dairy HHs that accessed cooperative, cafeteria, and consumer channels received a lower price per liter. The result is in agreement with the finding of Kuma et al. (2013) who revealed that the price offered by cooperative was lower than other milk market channels that pay based on cash mode.

The number of dairy cows owned by the household is positively and significantly $(\mathrm{p}<0.05)$ associated with the likelihood of choosing the cooperative channel and negatively $(\mathrm{p}<0.01)$ associated with the likelihood of choosing the cafeteria/restaurant channel, ceteris paribus. Herd size is positively correlated to milk volume, cooperative channels preferred large producers (D’Antoni, Mishra, \& Blayney, 2013) because of reduced transaction costs. This is consistent with the findings by Moturi et al. (2015) who revealed that the total number of cows owned by the $\mathrm{HH}$ had a positive and significant effect upon farmer participation in the cooperative channel. 
Contrary to a prior expectation, the quantity of milk sold is negatively and significantly ( $\mathrm{p}$ $<0.01)$ associated with the likelihood of selling to the cooperative channel, ceteris paribus. It reflects that dairy HHs were more likely to select milk market channel that paid in cash or that offered monthly payment. This finding is in line with that of Tsourgiannis et al. (2008), who revealed that farmers in Greece wanted to be sure that would be paid as well as wanted to receive their money quickly sold their milk to the dairy firms. These findings were also consistent with Moturi et al. (2015), who found that farmers in neighboring Kenya were more likely to sell milk and milk product through own distribution channel as compared to the cooperative channel.

\section{Conclusions and Policy Implications}

The study revealed that out of the total milk production, the milk market surplus accounted for 85.73\%. The majority of the HHs preferred cafeteria/restaurant $(35.91 \%)$ and consumer (35.91\%) channels, this shows the need to promote dairy cooperatives in terms of coverage and membership considering dairy farmer's competitive advantage so that its benefit reaches to all crossbreeds dairy farmers for holistic dairy development. The maximum milk yield/day/crossbreeds was found to be 20 liters, revealing the potential to improve the productivity of milk from the current average of 10 liters/day/crossbreeds, by improving the management system of the crossbreeds cows.

The result of the multivariate probit model revealed that separate estimation of milk market channel choice decision is biased, and the decisions to choose the four milk market channels are simultaneous. We observed a positive correlation between most of the milk marketing channels such as consumer and cooperative; consumer and cafeteria/restaurant; assembler/trader and cafeteria/restaurant, and assembler/trader and consumer channel. Besides, a negative correlation 
between cafeteria/restaurant and cooperative channel, and assembler/traders and cooperative channels.

Cooperative membership and physical distance from the milk market were identified as major determinants of milk market channel choice. Hence, policymakers should consider establishing new dairy cooperatives/milk collection centers in potential milk production and marketing areas to enable dairy farms to access the milk market and new dairy technologies through collective action. Moreover, there is a need to capacitate the existing dairy cooperatives in the milk quality management system, through training and facilitation of milk inspection, storage and collection equipment to insure milk safety along the milk market channel. On the other hand, dairy farmers should focus on improving the milk production capacity of crossbreeds by improving their genetic potential using Artificial Insemination technology and self-process their milk in order to produce niche market products and selling either milk directly to consumers through their own farm shops in order to gain better profit by adding value to their milk, as most of the milk producers sell their milk without processing.

\section{Abbreviations}

AI: Artificial Insemination; CSA: Central Statics Agency; EATA: Ethiopian Agriculture Transforamtion Agency; EIAR: Ethiopian Institute of Agricultural Research; ETB: Ethiopian Birr; HH: Household; PPS: Probability proportional to size; MVN: Multivariate normal distribution; Mt: Metric ton; OECD: Organisation for Economic Co-operation and Development; RUM: Random Utility Model.

\section{Availability of Data and Materials}


The author wants to declare that they can submit the data, and STATA Do file at any time based on publisher's request.

\section{Competing interests}

The authors declare that they have no competing interests.

\section{Funding}

Arsi University, College of Agriculture, and Environmental Science supported this research financially and logistically.

\section{Authors' Contributions}

Bedilu Demissie Zeleke: Writing-original draft of the manuscript, Methodology, and Analysis of data using STATA 14. Endashaw Terefe: Project proposal writing, Granting fund, Cross-section data collection, Reviewing, and Editing. Abiot Deddefo: Reviewing, and Editing. All authors have read and approved the final manuscript.

\section{Acknowledgments}

The authors would like to thank the sample respondents, enumerators, and staff of the agricultural and rural development bureau in the sampled urban and per-urban districts of Arsi Zone for their cooperation in providing necessary information and coordinating sample respondents. The financial support of Arsi University, College of Agriculture and Environmental Science is gratefully acknowledged.

\section{References}


Abera Negeri, M. (2017). Determinants of Market Outlet Choice of Coffee Producing Farmers in Lalo Assabi District, West Wollege Zone, Ethiopia: An Econometric Approach. Journal of Economics and Development, 19(2), 48-67.

Abera, S. (2016). Econometric Analysis of Factors Affecting Haricot Bean Market Outlet Choices in Misrak Badawacho District, Ethiopia. International Journal of Research Studies in Agricultural Sciences, 2(9), 6-12.

Amaya, N., \& Alwang, J. (2011). Access to Information and Farmer's Market Choice: The Case of Potato in Highland Bolivia. Journal of Agriculture, Food Systems, and Community Development, 1(4), 35-53.

Araña, J. E., \& León, C. J. (2007). Repeated dichotomous choice formats for elicitation of willingness to pay: Simultaneous estimation and anchoring effect. Environmental and Resource Economics, 36(4), 475-497.

Arinloye, D. D. A. A., Pascucci, S., Linnemann, A. R., Coulibaly, O. N., Hagelaar, G., \& Omta, O. S. W. F. (2015). Marketing Channel Selection by Smallholder Farmers. Journal of Food Products Marketing, 21(4), 337-357.

Balsevich, F., Schuetz, P., \& Edwin, P. (2006). Cattle Producers' Participation in Market Channels in Central America: Supermarkets, Processors, and Auctions. Agricultural Economics, pp. 1-12.

Baltas, G., \& Doyle, P. (2001). Random utility models in marketing research: A survey. Journal of Business Research, 51(2), 115-125.

Bardhan, D., Sharma, M. L., \& Saxena, R. (2012). Market Participation Behaviour of Smallholder Dairy Farmers in Uttarakhand: A Disaggregated Analysis. Agricultural Economics Research Review, 25(2), 243-254. 
Cappellari, L., \& Jenkins, S. P. (2003). Multivariate Probit Regression using Simulated Maximum Likelihood. The Stata Journal: Promoting Communications on Statistics and Stata, 3(3), 278-294.

Central Statistical Agency. (2013). Population Projection of Ethiopia for All Regions At Wereda Level from 2014 - 2017. Journal of Ethnobiology and Ethnomedicine, 3(1), 28.

Central Statistical Agency. (2017). Smallholder dairy production and marketing systems in Ethiopia: IPMS experiences and opportunities for market-oriented development. (Y. Tegegne, A., Gebremedhin, B., Hoekstra, D., Belay, B., \& Mekasha, Ed.). Central Statistical Agency.

Consult, T. a M. (2008). Dairy Investment Opportunities in Ethiopia. Study on Dairy Investment Opportunities in Ethiopia, (July), 59.

D’Antoni, J. M., Mishra, A. K., \& Blayney, D. (2013). Assessing participation in the milk income loss contract program and its impact on milk production. Journal of Policy Modeling, 35(2), 243-254.

Dekeba, A., Beuving, J., \& Ruben, R. (2016). Original Article How African Households Shop : Evidence from Dairy Chains in Ethiopia. The European Journal of Development Research. https://doi.org/10.1057/s41287-016-0062-3

Demissie, B., Komicha, H. H., Kedir, A., \& Asefa, S. (2018). Camel milk marketing channel choices for enhancing competitiveness in Eastern Ethiopia: Multinomial logit approach. Global Journal of Management and Business Research, 18(5), 1-10.

EATA. (2016). The Ethiopian Agriculture Transforamtion Agency(EATA): Annual Report 201516.

EIAR. (2018). Dairy Research Results (K. Melesse, Ed.), Eastern Africa Agricultural 
productivity Project (EAAPP). ISBN: 9789994466504.

Emana, B., Ketema, M., Mutimba, K. J., \& Yousuf, J. (2015). Factors Affecting Market Outlet Choice of Potato Producers in Eastern Hararghe Zone, Ethiopia. Journal of Economics and Sustainable Development, 6 (15), 159-173.

Gizaw, S., Tesfay, Y., Mekuriaw, Z., \& Mekasha, Y. (2017). Feed resources in the highlands of Ethiopia : A value chain assessment and intervention. LIVES Working Paper 27, (July), 150.

Greene, W. H. (2000). Econometric Analysis, 4th Ed, Prentice Hall, Englewood Cliffs.

Gujarati, D., \& Sangeetha, N. (2007). Basic Econometrics. Fourth Edition,. In The Economic Journal (Vol. 82). https://doi.org/10.2307/2230043

Hailu, A. (2017). Factors Affecting Onion Market Outlet Choices in Ejere District, West Shoa Zone, Oromia Region of Ethiopia. 34, 23-30.

Ishaq, M. N., Xia, L. C., Rasheed, R., \& Abdullah, M. (2017). Market Decision Preferences of Dairy Farmers Towards Traditional and Modern Channels of Milk Marketing: an Evidence From Punjab Province of Pakistan. International Journal of Food and Agricultural Economics, 5(3), 59-74.

Kihoro, E. M., Irungu, P., Nyikal, R., \& Maina, I. N. (2016). An analysis of factors influencing farmers ' choice of green gram marketing channels in Mbeere south-country, Kenya, 2016 Fifth International Confecence, September 23-26, 2016, Addis Ababa, Ethiopia 249331, African Association of Agricultrual Econmists (AAAE).

Kuma, B., Baker, D., Getnet, K., \& Belay, K. (2013). Factors affecting milk market outlet choices in Wolaita zone, Ethiopia. African Journal of Agricultural Research, (December 2015). https://doi.org/10.5897/AJAR11.2156 
Kumar, A., Staal, S., \& Singh, D. (2011). Smallholder Dairy Farmersâ $€^{\mathrm{TM}}$ Access to Modern Milk Marketing Chains in India. Agricultural Economics Research Review, 24(2), 243-253.

Lie, H., Rich, K. M., van der Hoek, R., \& Dizyee, K. (2018). An empirical evaluation of policy options for inclusive dairy value chain development in Nicaragua: A system dynamics approach. Agricultural Systems, 164(March), 193-222.

Mayberry, D., Ash, A., Prestwidge, D., Godde, C. M., Henderson, B., Duncan, A., ... Herrero, M. (2017). Yield gap analyses to estimate attainable bovine milk yields and evaluate options to increase production in Ethiopia and India. Agricultural Systems, 155(April), 4351.

Mcfadden, D. (1986). The Choice Theory Approach to Market Research. Marketing Science, 5(4), 275-297.

Mekuanint, G., \& Girma, D. (2017). Livestock feed resources, nutritional value and their implication on animal productivity in mixed farming system in Gasera and Ginnir Districts, Bale Zone, Ethiopia. International Journal of Livestock Production, 8(2), 12-23.

Mmbando, F. E., Wale, E., Baiyegunhi, L. J. S., \& Darroch, M. A. G. (2016). The Choice of Marketing Channel by Maize and Pigeonpea Smallholder Farmers: Evidence from the Northern and Eastern Zones of Tanzania. Agrekon, 55(3), 254-277.

Moturi, W. O., Obare, G. A., \& Kahi, A. K. (2015). Milk Marketing Channel Choices for Enhanced Competitiveness in The Kenya Dairy Supply Chain: A multinomial Logit Approach. Agriculture in an Interconnected World, 1-21.

Mutura, J. K., Nyairo, N., Mwangi, M., \& Wambugu, S. K. (2016). Analysis of Determinants of Vertical and Horizontal Integration among Smallholder Dairy Farmers in Lower Central Kenya. International Journal of Agricultural and Food Research, 5 (1), 83-90. 
Ndoro, J. T., Mudhara, M., Chimonyo, M., \& Hitayezu, P. (2015). Farmers 'Choice of Cattle Marketing Channels in Rural South Africa: A Transaction Cost Economics Perspective. International Conference of Agricultural Economics, $29^{\text {th }}$ Milan, Italy 2015.

Njuki, J., Kaaria, S., Chamunorwa, A., \& Chiuri, W. (2011). Linking smallholder farmers to markets, gender and intra-household dynamics: Does the choice of commodity matter? European Journal of Development Research, 23(3), 426-443.

Nyaga, J., Nyikal, R. N., \& Busienei, J. R. (2016). Factors influencing the choice of marketing channel by fish farmers in Kirinyaga County. 5th International Conference of the African Association of Agricultural Economists, 1-13.

OECD/FAO. (2017). OECD-FAO Agricultural Outlook 2017-2026, OECD Publishing, Paris. http://dx.doi.org/10.1787/agr_outlook-2017-en.

Oromia Finance and Economic Development Bureau. (2011). Physical and Socio Economic Profile of Arsi Zone and Districts (Y. Etefa \& K. Dibaba, Eds.). Bureau of Finance and Economics Development- Regional data and Infomation Core Process, Addis Ababa, Ethiopia.

Ruben, R., Dekeba Bekele, A., \& Megersa Lenjiso, B. (2017). Quality upgrading in Ethiopian dairy value chains: dovetailing upstream and downstream perspectives. Review of Social Economy, 75(3), 296-317.

Tapsuwan, S., Burton, M., \& Perriam, J. (2010). A multivariate probit analysis of willingness to pay for Cave conservation: A case study of Yanchep National Park, Western Australia. Tourism Economics, 16(4), 1019-1035.

Tarekegn, K., Haji, J., \& Tegegne, B. (2017). Determinants of honey producer market outlet choice in Chena District, southern Ethiopia: a multivariate probit regression analysis. 
Agricultural and Food Economics, 5(1).

Tegegne, A., Gebremedhin, B., Hoekstra, D., Belay, B., \& Mekasha, Y. (2013). Smallholder dairy production and marketing systems in Ethiopia: IPMS experiences and opportunities for market-oriented development. IPMS (Improving Productivity and Market Success) of Ethiopian Farmers Project Working Paper 31. Nairobi: ILRI. (31), 78.

Tsourgiannis, L., Eddison, J., \& Warren, M. (2008). Factors affecting the marketing channel choice of sheep and goat farmers in the region of east Macedonia in Greece regarding the distribution of their milk production. Small Ruminant Research, 79(1), 87-97.

USAID/Land O'Lakes. (2010). The next stage in dairy development for Ethiopia Dairy Value Chains: Dairy Value Chains, End Markets and Food Security Cooperative Agreement 663A-00-05-00431-00. Land O'Lakes Inc., Adis Ababa, Ethiopia (2010), (November), 88.

Yami, M., Begna, B., Teklewold, T., Lemma, E., Etana, T., \& Legese, G. (2012). Analysis of the dairy value chain in Lemu-Bilbilo District in the Arsi Highlands of Ethiopia. (October).

Yilma, Z., Guernbableich, E., \& Sebsibe, A. (2011). A Review of the Ethiopian Dairy Sector. Ed. Rudolf Fombad, Food and Agriculture Organization of the United Nations, Sub Regional Office for Eastern Africa (FAO/SFE), Addis Ababa, Ethiopia, pp 81. 